\title{
The Augmented Monetary Model and Exchange Rate Fluctuations; Case of RUB/USD
}

\author{
Olga Zhuk ${ }^{1} \&$ Behrooz Gharleghi, ${ }^{1,2}$ \\ ${ }^{1}$ Faculty of Business and Management, Asia Pacific University of Technology and Innovation, Bukit Jalil, Kuala \\ Lumpur, Malaysia \\ ${ }^{2}$ Centre of Socio-Economics of Ageing (CSEA), Asia Pacific University of Technology and Innovation, Kuala \\ Lumpur, Malaysia \\ Correspondence: Behrooz Gharleghi, Faculty of Business and Management, Asia Pacific University of \\ Technology and Innovation, TPM, 57000, Bukit Jail, Kuala Lumpur, Malaysia. Tel: 60-19-615-3515. E-mail: \\ behrooz@apu.edu.my
}

Received: November 2, 2014 Accepted: January 27, 2015 Online Published: April 20, 2015

doi:10.5539/ass.v11n10p231 URL: http://dx.doi.org/10.5539/ass.v11n10p231

\begin{abstract}
The present study is examining the impact of macro-economic variables towards exchange rate determination in Russian Federation currency, Ruble. In order to achieve this aim, the monetary model of exchange rate determination is applied here. This study contributes to the literature by adding a new variable of Oil Price into the flexible price monetary model. This objective is examined through a regression analysis. The data is collected from 1998-2013 and natural logarithm is taken. The empirical results revealed that the augmented monetary model is not validated. But there found a significant relationship between oil price and Ruble. The industrial production function is identified not to be significant in the model.
\end{abstract}

Keywords: exchange rate, oil price, Russia, interest rate, money supply, IPI

\section{Introduction}

The cause roots of the 1998 crisis in Russia are coming from the country's economic structure, environment and politics. During those years, tight monetary policy has been combined with soft budgetary policy (Kuvalin, 2002). The push to crisis was given by two external factors: sudden fall of world prices for energy complex and fuel (Mozhaiskov, 1999) and Southeast Asia crisis of 1997 (Gaidar \& Chubais, 2011). In order to stabilize this situation, government and central bank of Russia (CBR) applied extraordinary measures: 17th of August, 1998, the default of government debt has been declared. At the same time, it was announced refusal of holding unnatural stable exchange rate RUB/USD. As it is seen, post-crisis time was challenging for Russia, since government needed to be careful in making decisions and properly maintain economy. It was affecting both internal and external situation of the country. Since Russia is the largest country and it has huge influence on others, the economy and policy are expected to be well-organised. As sequence, the current research is made in order to analyse the post crisis situation, as well as to trace and find possible solutions for faced problem: currency value instability in Russian Federation during post-crisis time of 1998-2013, which may arise from the impact of macro-economic indexes (chosen in this paper: oil price, interest rate, money supply, and industrial production index) on exchange rate in Russia. In order to determine the relationship between these variables, the statistical approach is going to be used; therefore, the data applied in this study are monthly and spanning from 1998 to 2013. Data is going to be calculated and analysed by SPSS software basing on the augmented flexible price monetary model of exchange rate determination.

Before setting the objectives, the dependent variable has to be identified. The exchange rate is the price on the current market, for which one currency can be exchanged for another. Coming further, there are five main stated objectives that were picked up in this research according to mentioned above the most important macro variables. Oil price is a category that used to be mentioned along with exchange rate in amount of discussion, and such variables as interest rate, money supply and output are being the most meaningful in this question; however, in order to complete current study more precisely, the chosen indexes are going to be RUB/USD exchange rate, crude oil price, interest rate (MIACR, 1-day; \%), money supply (M2) and industrial production index (\%). 
Therefore, the main objective of the study is to investigate whether oil price, money supply, output, and interest rate can affect the currency value in Russia. Oil price is determined towards oil future contracts (which have the leading role in determining the price) by supply, demand and market sentiment. The aim of the research is to analyse price of oil and rate of Rouble, and by building regression to identify the relation between these two indexes. Money supply is an amount of monetary assets available at a specific time. There are four types of money supply that are including all cash assets in circulation, short-term deposits, and long-dated deposits. Thus, defining relationship between money supply and Rouble exchange rate data during the given period of years from 1998 to 2013 is another important case.

Interest rate is an instant rate, at which central banks make loans to the commercial banks. If interest rate is reduced, the inflations rate is going to increase and national currency to weaken, so business activities will grow, and vice versa. Consequently, interest rate might be a reason of fluctuations of exchange rate. Industrial production index is an indicator that helps to measure all changes in production for the manufacturing and utilities. In current research, IPI is representing the output due to the lack of availability of monthly data for output; and also might be used as measurement for inflation rates, since high IPI is able to lead to huge inputs and rapid inflations. So, analysing of this index is able to provide possible ways of affecting the exchange rate of national currency of Russia.

\section{Literature Review}

\subsection{Exchange Rate}

The exchange rate is the price on the current market, for which one currency can be exchanged for another. Exchange rate plays an essential role for country's effectiveness in competition. The rate is to be given by international demand and supply levels, but it is not easy to determine exchange rate of another country, since the market is huge and unstable. The RUB/USD average exchange rate valued as 23.61; starting from 1993 until 2013 time the highest data was 36.39, in 2009, February, and the lowest was 0.98, in 1993, August. The RUB/USD exchange rate specifies on how much the USD is currently worth in terms of the RUB. The estimation and exchange of the RUB/USD spot exchange rate is happening at the same day, but the RUB/USD forward rate while being estimated today, get delivered and paid only on set future date (tradingeconomics.com, 2014). Among others, Gharleghi and Shaari (2012), Gharleghi, Shaari, and Sarmidi (2014), have studied the exchange rate determination in Malaysia using monetary model and found support of this model towards MYR/USD.

\subsubsection{Oil Price}

Differentiating from other products, oil price is determined not toward the tangible product, but toward oil future contracts by supply, demand and market sentiment. Oil future contracts are being thoroughly operated by speculators and taking the leading role in determining the price (Andreoli, 2011). Apparently, oil is going to be in high demand in coming future, despite of how the price is determined.

Russia is being a main producer and exporter of oil and its economic growth is being driven by energy exports. Within the country, Russia gets half of its energy needs from natural gas. According to data in 2012, Russia had surpassed Saudi Arabia in the category of the top crude oil producer. However, high taxes and export duties are still affecting country's oil sector. In 2011, in order to make situation better, export duties were decreased for crude oil to $60 \%$ and for petroleum to $65 \%$, but producers remain facing high taxes.

\subsubsection{Interest Rate}

Interest rate is instant rate, at which central banks make loans to the commercial banks. So by moving this rate, central banks actually can influence interest rates in commercial banks, thereby inflation level and currency exchange rate. According to Keynes (1936), if interest rate is reduced, the inflations rate is going to increase and national currency to weaken, so business activities will grow, and vice versa. In Russia, interest rate is verified by the Central Bank, and the average during the period of time from 1991 till 2013 consists of 50.41 per cent. The highest result was $210.00 \%$, April, 1994, and the lowest was $7.75 \%$, June, 2010 (tradingeconomics.com, 2014).

\subsubsection{Money Supply}

Money supply is an amount of monetary assets available at a specific time. There are four types of money supply. First two (M0 and M1 - narrow money) are including all notes and coins are being in use and other assets that can be easily converted into cash. The third type is M2 consists of M1 and short-dated deposits in banks. M3 is including M2 with long-dated deposits. M2 is mostly used in academic literature affecting other macroeconomic variables. Russia Money Supply is stated by the Central Bank. Average money supply M0 is 1640.58 RUB 
billion from 1990 until 2013. The highest data is 6470.30 RUB Billion, 2013, and the lowest is 0.10 RUB Billion, 1990. Money Supply M1 averaged as 4206.74 RUB Million from 1995 until 2013. The top result was 14001.80 RUB Million, 2013, and the lowest is 106.31 RUB Million, 1995. Money Supply M2 averaged as 10674.40 RUB Billion from 2000 until 2013, being the highest as 28506.10 RUB Billion, 2013, and the lowest as 1090.10 RUB Billion, 2001, (tradingeconomics.com, 2014).

\subsubsection{Industrial Production Index}

Industrial production index is an indicator that helps to measure all changes in production for the manufacturing and utilities; therefore it is good index for gross domestic product or output (Gharleghi, Shaari, and Shafighi, 2014). IPI is a substantial implement in estimating possible future output and performance in economic policy. IPI is also might be used as measurement for inflation rates, since high IPI is able to lead to huge inputs and rapid inflations. Industrial production index is given by the Federal State Statistics Service. The average Russia IPI is $2.70 \%$ from 2006 till 2013. The highest is $12.60 \%, 2010$, and the lowest is $-16.90 \%$, 2009, (tradingeconomics.com, 2014).

Therefore, based on the above literature, following hypotheses will be tested in this paper;

$\mathrm{H}_{0}$ : there is no relationship between money supply and exchange rate.

$\mathrm{H}_{0}$ : there is no relationship between output and exchange rate.

$\mathrm{H}_{0}$ : there is no relationship between interest rate and exchange rate.

$\mathrm{H}_{0}$ : there is no relationship between oil price and exchange rate.

There are few points that are expected to meet in this research. First of all, despite the fact that all the chosen indicators are macro variables, it is probable that Industrial Production Index will not have significant relation to the exchange rate, since the output is defined not only by the price, but also by physical units and other data. Therefore, it might affect the R-square of the regression (R-square will be lower). Another expectation is to reach a final equation of calculating the approximate exchange rate in future, basing on the augmented monetary model and unstandardized coefficients, which are to be extracted from the regression calculation by SPSS. And at last, it is expected to provide a rough image on the future years.

\subsection{Flexible Price Monetary Model}

In order to explore the fluctuations of the exchange rate, in early 1970s the monetary model has been introduced that represent relations between exchange rate and monetary basics and relates to forecasting of exchange rates. According to this model, the price level is reported by the money supply and demand. Moreover, the prices in domestic and foreign countries are to be given in the same currency (Rapach \& Wohar 2002). By using monetary policy, government targets certain level of money supply or interest rate. Policy makers apply the monetary model for identifying the effect of monetary policy to economic variables, as well as effects of decision on economy.

Exchange rate monetary models are divided into two groups: the flexible-price model of Frenkel (1976) and Mussa $(1979,1986)$ and the sticky-price monetary model of Dornbusch (1976), Frenkel (1979), and Neely \& Sarno (2002). The first model accepts that prices respond to changes instantly, and given volume of currency will be back with the same volume of products, exchange rate changes according prices that change in response to new policies; and the second model allows nominal and real exchange rate overrunning above the long-term stability levels (Neely \& Sarno, 2002).

\subsection{Theory of Flexible Price Monetary Model}

Exchange rate, as defined above, is the relative price of two currencies from two countries, e.g. Russian Ruble over US Dollar. Purchasing power parity and interest rate parity are coming to the models to define equilibrium conditions. The first block of the monetary model accepts that PPP remains continuously:

$$
S_{t}=p_{t}-p_{t}^{*}+c
$$

In this situation "c" is a constant, "s" is the logarithm of exchange rate in units of domestic currency per foreign currency, and "p" and "p*" are domestic and foreign price levels respectively, following Civcir (2001). If c =0, equation (1) provides that absolute PPP remains, and if $c^{\prime}$ is 0 , equation (1) provides that relative PPP remains.

According to the second block of the model, in domestic and foreign countries operates money demand that is stable and the money market equilibrium depends on the logarithm of real income, " $y$ ", and the logarithm of money supply, "m", and the nominal interest rate, "i", by Civcir (2001). Asterisks in this situation are denoting foreign variables. So, in domestic and foreign countries the monetary balance is given by: 


$$
\begin{gathered}
m_{t}=p_{t}+\beta_{2} y_{t}-\beta_{3} i_{t} \\
m_{t}^{*}=p_{t}^{*}+\beta_{2}^{*} y_{t}^{*}-\beta_{3}^{*} i_{t}^{*}
\end{gathered}
$$

For symbols " $\mathrm{m}_{\mathrm{t}}$ " and " $\mathrm{m}{ }_{\mathrm{t}}$ " are the domestic supply and foreign money supply; for " $\beta_{2}$ " is being the income elasticity of money demand, and " $\beta_{3}$ " is the interest rate semi-elasticity. On reordering equation (2) and (3) for domestic and foreign price levels and replacing into equation (1) it brings to flexible price monetary model of exchange rate equation of Bilson (1978), and Hodrick (1978):

$$
s_{t}=\beta_{1}\left(m_{t}-m_{t}^{*}\right)-\beta_{2}\left(y_{t}-y_{t}^{*}\right)+\beta_{3}\left(i_{t}-i_{t}^{*}\right)+c+\varepsilon_{t}
$$

Here " $\beta$ " is parameters and "c" is a random constant, and " $\varepsilon_{t}$ " is a disturbance term. Equation (4) presumes that balance exchange rate is determined by relative additional money supplies. In equation (4) the nominal interest rate is brought by two components: the real interest rate and the expected inflation rate:

$$
\begin{aligned}
& i_{t=r_{t}}+\pi_{t}^{\varepsilon} \\
& i_{t}^{*}=r_{t}^{*}+\pi_{t}^{\varepsilon^{*}}
\end{aligned}
$$

Here " $\mathrm{r}_{\mathrm{t}}$ " and " $r_{t}^{*}$ " are the domestic and foreign real interest rate and " $\pi_{\mathrm{t}}$ " and " $\pi_{t}^{\varepsilon}$ " are expected rates of domestic and foreign inflation correspondingly. Supposing that real interest rates are balanced in both countries;

$$
i_{t}-i_{t}^{*}=\pi_{t}^{\varepsilon}-\pi_{t}^{\varepsilon}
$$

Thus, equation (4) again can be recorded as:

$$
s_{t}=\beta_{1}\left(m_{t}-m_{t}^{*}\right)-\beta_{2}\left(y_{t}-y_{t}^{*}\right)+\beta_{3}\left(i_{t}-i_{t}^{*}\right)+c+\varepsilon_{t}
$$

The equation (8) is the Flexible Price Monetary Model (FPMM). The quantity of the relative money supply is positive and equal to one of based on the neutrality of money. Increasing by percentage in money supply comes along with prices increase by the same percentage. If PPP holds uninterruptedly, means that depreciation of the domestic currency (" $\mathrm{s}_{\mathrm{t}}$ ") increase by the same amount, in order to restore balance. The main supposition of flexible price monetary model (FPMM) is that the purchasing power parity (PPP) is held until an environmental exchange rate's shockwave occurs (Nelson, 1991).

In this paper, we add a new variable of "oil price" into the monetary model to check whether the augmented model is held for RUB/USD. The final equation hence is written below:

$$
s_{t}=\beta_{1}\left(m_{t}-m_{t}^{*}\right)-\beta_{2}\left(y_{t}-y_{t}^{*}\right)+\beta_{3}\left(i_{t}-i_{t}^{*}\right)+\beta_{4}\left(o_{t}-o_{t}^{*}\right)+c+\varepsilon_{t}
$$

where, $o$ is the oil price in home and foreign country.

\section{Methodology}

The data for macroeconomic variables is collected from January 1998 till July 2013 form international financial statistic by international monetary fund. The data for oil price is obtained from Russian ministry of energy. SPSS software is a used to provide the analysis of statistics. It provides graphical interface, so the correlation and regression are visible clearly and understandable. For this study, correlation and regression analyses are utilised, since they are extensively used in literature (Gharleghi \& Chan, 2013).

\section{Empirical Findings}

Descriptive Statistics in this paper represent the brief introduction to the collected data by providing to the viewer the amount of showings for each of variable, as well as the minimum and maximum indicators. As for example, the highest interest rate reached out during post-crises time in Russia was $139.7 \%$, or the price for oil jumped up to 133.87 USD per barrel, despite the crisis in 2008-2009. 
Table 1. Descriptive statistics

\begin{tabular}{llllll}
\hline Variables & $\mathrm{N}$ & Minimum & Maximum & Mean & Std. Deviation \\
\hline Exchange Rate & 187 & 6.03 & 35.76 & 27.57 & 5.36 \\
Money Supply & 187 & 350.50 & 28743.30 & 8972.05 & 8512.62 \\
Industrial Production Index & 187 & 61.78 & 141.36 & 107.05 & 20.74 \\
Interest Rate & 187 & 1.00 & 139.70 & 8.82 & 14.21 \\
Oil Price & 187 & 10.13 & 133.87 & 57.33 & 34.83 \\
\hline
\end{tabular}

\subsection{Data Correlation}

Data correlation is significantly helpful in defining the relationship between DV and IVs. However, collected data's amplitude is too wide; therefore, data has been calculated as natural logarithm (ln) for each of variables. Basing on the correlation provided by SPSS analysis (Table 2), all of the IVs are tightly related to the DV, since the statistical significance of each is equal to 0.000 and hence it is less than 0.05 (2-tailed). Thus, it is possible to conclude that relationship between DV and each of IVs is strong. The Pearson Correlation also shows the type of the relationships between the variables, as for example, all of the IVs, except for Interest Rate, have positive relationship with exchange rate. The negative relationship of Interest Rate towards exchange rate can be determined as inversely, which means that if Interest Rate increases, the exchange rate will decrease.

Table 2. Correlation test

\begin{tabular}{llllll}
\hline & & OP & MS & IR & IPI \\
\hline \multirow{3}{*}{ ER } & Pearson Correlation & $.433^{* *}$ & $.484^{* *}$ & $-.557^{* *}$ & $.496^{* *}$ \\
& Sig. (2-tailed) & .000 & .000 & .000 & .000 \\
& $\mathrm{~N}$ & 187 & 187 & 187 & 187 \\
\hline
\end{tabular}

Note: Exchange Rate (RE), Oil Price (OP), Money Supply (MS), Interest Rate (IR), Industrial Production Index (IPI)

\subsection{Regression Analysis}

However, regression analysis is known to be more detailed while identifying the significance and relationships between variables; therefore, it is very useful for hypotheses testing. Next table considered is the ANOVA table (Table 3), which shows that significance is less than 0.05 , actually equals to 0.000 , which confirms that all the IVs are strongly related to the DV and also shows that there is no significant difference between the mean of the variables. The F-test shows how IVs are on average superior/inferior comparing to the others. The advantage of ANOVA F-test is that it is not needed to compare all the IVs separately, and the disadvantage is that if null hypothesis is rejected, then it is not known how each IV is different from others. Current regression shows that $\mathrm{F}$ $(4,182)$ is equal to 29.224 (uncommonly large), what means that the mean and variances between the variables are not equal and therefore the null of similarity of mean in all variables are rejected.

Table 3. ANOVA results

\begin{tabular}{llllll}
\hline & Sum of Squares & $\mathrm{df}$ & Mean Square & F & Sig. \\
\hline Regression & 7.673 & 4 & 1.918 & 29.224 & .000 \\
Residual & 11.946 & 182 & .066 & & \\
Total & 19.619 & 186 & & & \\
\hline
\end{tabular}

Dependent Variable: ER, Predictors: (Constant), IPI, IR, OP, and MS

Model Summary table is provided as following (Table 4) and showing the R square, which identifies the percentage of the DV's explanation by IVs. In other words, it means that $39.1 \%$ of the exchange rate variations explained by oil price, money supply, interest rate and industrial production index. 
Table 4. Model summary, regression

\begin{tabular}{lllll}
\hline Model & R & R Square & Adjusted R Square & Std. Error of the Estimate \\
\hline 1 & $.625^{\mathrm{a}}$ & .391 & .378 & .25620 \\
\hline
\end{tabular}

Based on the coefficient estimation table (Table 5), all the IVs except Industrial Production Index are significantly affecting the exchange rate, since the $\mathrm{p}$-value of these variables are less than 0.05 (sig.oP $=0.003$, sig. ${ }_{\mathrm{MS}}=0.003$, sig. $\cdot \mathrm{IR}=0.000$, and $\mathrm{sig} \cdot \mathrm{IPI}=0.621$ ). These findings prove the strong relationships between these variables. Therefore, recalling the earlier hypotheses, all of the null hypotheses $\left(\mathrm{H}_{0}\right)$ are rejected except for IPI. From these findings it can be concluded that the augmented flexible price monetary model is not validated for the case of RUB/USD over the period of 1998-2013 because one of the variables found to be not-significant.

Table 5. Coefficients estimation results

\begin{tabular}{lllll}
\hline Variables & Beta & Std. error & t-stat & Sig. \\
\hline Constant & 2.330 & 1.387 & 1.680 & .095 \\
Money Supply & .180 & .059 & 3.026 & .003 \\
Output & .191 & .386 & .495 & .621 \\
Interest Rate & -.172 & .029 & -5.956 & .000 \\
Oil Price & -.302 & .101 & -2.982 & .003 \\
\hline
\end{tabular}

The sign of coefficients shows that there is a positive relationship between money supply and exchange rate, while this relationship is negative for interest rate and oil price. In order to do a robust check for FPMM, this theory is validated without oil price, i.e., next table shows the result of coefficient estimation for the original theory.

Table 6. Coefficients estimation results

\begin{tabular}{lllll}
\hline Variables & Beta & Std. error & t-stat & Sig. \\
\hline Constant & 3.820 & 1.321 & 2.892 & 0.004 \\
Money Supply & 0.093 & 0.052 & 1.765 & 0.079 \\
Output & -0.222 & 0.368 & -0.605 & 0.545 \\
Interest Rate & -0.168 & 0.029 & -5.736 & 0.000 \\
\hline
\end{tabular}

Table 6 revealed that the coefficients for money supply and output are not significant at 5\% and therefore this theory is not validated for RUB/USD.

\section{Conclusion}

This paper analysed the influence of money supply, interest rate, industrial production index, and oil price on the exchange rate fluctuations in Russia over the period of 1998-2013. It is hypothesized that these variables do not have any significant impact on the exchange rate in Russia. Based on the regression results from augmented model, all of the null hypotheses have been rejected, excluding the hypothesis for the industrial production index due to non-significance in the regression, which has been expected. However, running regression without output did not provide higher R-square. Therefore, the augmented monetary model is not validated for the case of Russia. To provide a better understanding for the flexible price monetary theory, we applied this model without any added variable to test the validity of the theory. After testing the original theory, we identified that this model is also not validated because: money supply and output are found to be non-significant in the model. Thus, the expectation for the ability to provide the equation that will calculate the approximate exchange rate has not been met. Finalising the research, it has been surprising to find that both the original theory and also the augmented theory are not validated in the case of Russian currency over USD.

\section{References}

Andreoli, D. (2011). Market Fundamentals and the Problem with Oil Prices. Retrieved from http://oilprice. com/Energy/Oil-Prices/Market-Fundamentals-And-The-Problem-With-Oil-Prices.html

Bilson, J. F. O. (1978). Rational Expectations and the Exchange Rate. In J. A. Frankel, \& G. J. Harry (Eds.), The 
Economics of Exchange Rates. Addison-Wesley.

Civcir, I. (2001). The monetary model of the exchange rate under high inflation: Long-run relationship and misalignment of Turkish Lira. Retrieved from http://www.erf.org.eg/CMS/uploads/pdf/1185354246_F-B_ Irfan_Civir_(The_Monetary).pdf

Dornbusch, R. (1976). Expectations and exchange rate dynamics. Journal of Political Economy, 84, 1161-1176. http://dx.doi.org/10.1086/260506

Frenkel, J. A. (1976). A monetary approach to the exchange rate: Doctrinal aspects and empirical evidence. Scandinavian Journal of Economics, 78, 200-224.

Frenkel, J. A. (1979). On the Mark: A theory of floating exchange rates based on real interest differentials. American Economic Review, 69, 610-622. http://dx.doi.org/10.2307/3439924

Gaidar, E., \& Chubais, A. (2011). Fork in the Modern History of Russia, OIG, 168.

Gharleghi, B., \& Shaari, A. H. (2012). Is Monetary Variable A Determinant in the Ringgit-Dollar Exchange Rates Model? A Cointegration Approach. Sains Malaysiana, 41(9), 1163-1169.

Gharleghi, B., Shaari, A. H., \& Shafighi, N. (2014). Predicting exchange rates using A Novel "Cointegration based Neuro-Fuzzy System". International Economics, 137, 88-103. http://dx.doi.org/10.1016/j.inteco.2013. 12.001

Gharleghi, B., Shaari, A. H., Sarmidi, T. 2014. Application of the Threshold Model for Modelling and Forecasting of Exchange Rate in Selected ASEAN Countries. Sains Malaysiana, 43(10), 1609-1622.

Hodrick, R. J. (1978). An Empirical Analysis of the Monetary Approach to Determination of the Exchange rate. In J. A. Frankel, \& G. J. Harry (Eds.), The Economics of Exchange Rates. Addison-Wesley.

Kuvalin, D. (2002). Behavior of enterprises as a factor of macroeconomic dynamics in the Russian economy in transition. Russian Academy of science, 13(6), 563-567.

Mozhaiskov, O. (1999). Russia's balance of payments for 1998. Retrieved from http://kommersant.ru/ $\operatorname{doc} / 218270$

Mussa, M. (1979). Empirical regularities in the behavior of exchange rates and theories of the foreign exchange market. Carnegie-Rochester Conference Series on Public Policy, 11(1), 9-57. http://dx.doi.org/10.1016/ 0167-2231(79)90034-4

Mussa, M. (1986). Nominal Exchange Rate Regimes and the Behavior of Real Exchange Rates: Evidence and Implications. Carnegie-Rochester Conference Series on Public Policy, 25, 117-213. Amsterdam: North-Holland Publishing Company. http://dx.doi.org/10.1016/0167-2231(86)90039-4

Neely, C. J., \& Sarno, L. (2002). How well do monetary fundamentals forecast exchange rates? Federal Reserve Bank of St. Louis. Working Papers, 7, 51-74.

Nelson, D. B. (1991). Conditional Heteroskedasticity in Asset Returns: A New approach. Econometrica, 59(2), 347-370. http://dx.doi.org/10.2307/2938260

Rapach, D. E., \& Wohar, M. E. (2002). Testing the Monetary Model of Exchange Rate Determination: New Evidence from a Century of Data. Journal of International Economics, 58, 359-385. http://dx.doi.org/10. 1016/S0022-1996(01)00170-2

Tradingeconomics.com. (2014a). Russia Gross Domestic Product. Retrieved from http://www.tradingeconomics. com/russia/gdp

Tradingeconomics.com. (2014b). Russia Industrial Production. Retrieved from http://www.tradingeconomics. com/russia/industrial-production

Tradingeconomics.com. (2014c). Russia Interest Rate. Retrieved from http://www.tradingeconomics.com/ russia/interest-rate

Tradingeconomics.com. (2014d). Russia Money Supply. Retrieved from http://www.tradingeconomics.com/ russia/money-supply-m0

Tradingeconomics.com. (2014e). Russian Ruble. Retrieved from http://www.tradingeconomics.com/russia/ currency

\section{Copyrights}

Copyright for this article is retained by the author(s), with first publication rights granted to the journal.

This is an open-access article distributed under the terms and conditions of the Creative Commons Attribution license (http://creativecommons.org/licenses/by/3.0/). 